KRZYSZTOF HILMAN

JAGIELLONIAN UNIVERSITY, KRAKÓW

\title{
THE STORY ABOUT THE INTRODUCTION \\ OF IDOLATRY IN MALALAS' CHRONICLE: \\ THE INTERRELATIONSHIP BETWEEN \\ MALALAS, THE EXCERPTA SALMASIANA AND ANACEPHALEOSIS
}

KEYWORDS: John Malalas, Epiphanius of Salamis, John of Antioch, Serug, Christian world chronicle, Terah

Many scholars pointed out the efforts made by Malalas, a $6^{\text {th }}$-century Byzantine chronographer, to unify Jewish, Greek and Roman history into a unitary world history. ${ }^{1} \mathrm{He}$ was by no means the first to do it, but certainly his work represents a whole new level in this respect. ${ }^{2}$ The novelty, or rather peculiarity of the stories which fill the books of his world Chronicle, especially of those concerned with mythical and biblical times, leads to an obvious question: where did he take them from? What were his sources and how much should we attribute to his ingenuity?

This question has received some attention ${ }^{3}$, but certainly not enough. In this paper we will try to shed some light on this problem

1 Most recently Berthelot 2004, Beaucamp 2006, Pernet 2007.

2 A good review of mythological and biblical content of Malalas' Chronicle can be found in Horling 1980. The best general introduction to Malalas and his work is still Jeffreys et al. (eds.) 1990. See also Beaucamp et al. (eds.) 2004, Agusta-Boularot et al. (eds.) 2006.

3 Still the most comprehensive work is Jeffreys 1990 with up-to-date bibliography. More recent works of a narrower scope include Garstad 2002, Garstad 2005, Garstad 2009, D'Alfonso 2006. Beaucamp 2006 and my unpublished PhD thesis entitled "Sources of the first 9 books of Malalas' Chronicle and their interpretation”, Kraków 2014. 
by examining a short biblical story about Serug, Terah, Hellen and the introduction of idolatry. ${ }^{4}$ We will try to identify the ultimate source of this story, which in turn will tell us something about the relationship between Malalas and the so-called Excerpta Salmasiana. ${ }^{5}$ The Excerpta Salmasiana are of great importance in this paper, and since this work is not a very well known piece of historical writing, even to specialists, and for those who are familiar with it, it has been a source of contention, we think that a short recapitulation of the scholarly discussion connected with it will serve well as an introduction to our more detailed studies. ${ }^{6}$

\section{JOHN OF ANTIOCH, EXCERPTA SALMASIANA AND JOHN MALALAS}

John of Antioch, ${ }^{7}$ because of his name and place of origin, was sometimes identified with John Malalas and was often confused with him $^{8}$. It is clear, however, that they were two different chronographers, though it is not quite certain whether John of Antioch lived and worked before or after John Malalas. The chronographical work of John of Antioch survived in much worse condition than that of John Malalas, that is to say, we have only fragments of his work. Because of this many scholars tried to reconstruct the content of his work from various fragments scattered among other works. One of the most important collections of fragments that was used to reconstruct the work of John of

4 Malalas 38.7 - 40.53. We employ the most recent edition of Malalas' Chronography edited by Thurn (Thurn Johannes (ed.), Ioannis Malalae Chronographia, Berlin 2000), all references to Malalas' text follow this edition.

5 This is a collection of extracts from some historical works. The most comprehensive recent coverage of this work can be found in Mariev's and Roberto's introductions to their editions of fragments of the Chronicle of John of Antioch: Roberto 2005: LIIILXXIII, Mariev 2008: 26*-29*.

6 The best review of the scholarship devoted to this question can be found in Mariev's introduction to his edition of John of Antioch's work (Mariev 2008: $4 *-8 *$ ), and our recapitulation is based on it.

7 On this author and his work see Roberto 2005: XI - CXXIV, and Mariev 2008: $3 *-56 *$.

$8 \quad$ See Patzig 1892. 
Antioch is the Excerpta Salmasiana, which is a collection of excerpts from chronicles. ${ }^{9}$ The reason for doing so is quite straightforward: in the beginning of this collection it is written that the fragments come from the work of John of Antioch. ${ }^{10}$ Some of these fragments, and especially those concerned with mythological and biblical times, are very similar to the material found in Malalas, which started a discussion on the relationship of those two authors.

Yet from the very beginning in the efforts to reconstruct the content of the Chronography of John of Antioch some scholars voiced their doubts about the validity of ascribing the fragments found in the Excerpta Salmasiana to the work of John of Antioch. In the first place Boissevain ${ }^{11}$ and Sotiriadis ${ }^{12}$ stated that the Excerpta cannot be attributed in its entirety to the work of John of Antioch because most of the fragments found there are too different in style and content from the so-called Constantine Fragments (fragments of John of Antioch's work incorporated into works of Constantine Porphyrogenitus). ${ }^{13}$ This argumentation was corroborated by a discovery made by De Boor, who found in some manuscripts of the Excerpta a marginal note which says

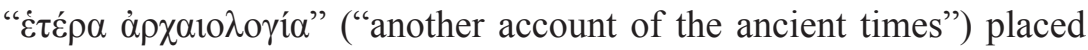
just after the first fragment. ${ }^{14}$

These arguments against attributing the Excerpta fragments to John of Antioch were not met with general approval. Probably the staunchest supporter of such attribution of the Excerpta to the work of John of Antioch was Patzig, who firstly rallied against arguments made by Boissevain and Sotiriadis ${ }^{15}$ saying that all the differences can stem from the redaction made by the epitomator. Later he also tried to argue that the

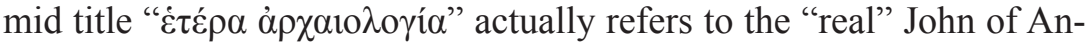
tioch, whereas the first title, which actually mentions John of Antioch,

\footnotetext{
9 This collection was used in the first modern edition of John of Antioch's fragments published by Karl Wilhelm Ludwig Müller in 1851 and more recently in the edition prepared by Umberto Roberto (Roberto 2005).

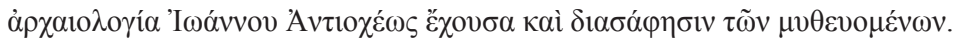

Boissevain 1887.

Sotiriadis 1888.

Mariev 2008: 17*-20*.

De Boor 1899.

15 Patzig 1892: 22.
} 
does not refer to him. ${ }^{16}$ Many scholars followed his claim, and among others Umberto Roberto, who is one of the most recent editors of the John of Antioch's Chronicle. ${ }^{17}$ However, Roberto was not prepared with the arguments Patzig gave and came up with his own theory. He postulates the existence of an intermediary work (some kind of a chronicle), which would have derived from the work of John of Antioch, but which would have added some other material. ${ }^{18}$ This work, according to Roberto, would have been a source for the epitomator, the author of the Excerpta, for the fragments which appear after the aforementioned

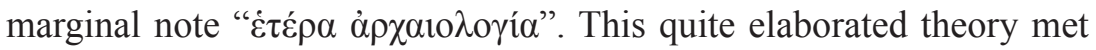
with some criticism for sacrificing the simplest and the most straightforward reasoning on the altar of esoteric theories, ${ }^{19}$ but any hard proof against Patzig's and Roberto's theories was not offered.

\section{THE EXCERPTA SALMASIANA AND MALALAS}

The Excerpta Salmasiana in many of its parts bear so much resemblance to the work of Malalas, that the only explanation here could be the existence of a common source. ${ }^{20}$ This is the case of almost all of the mythological and biblical accounts found in two works which accounts roughly for one third of Malalas Chronicle. These accounts are not only similar but there are for the most part also unique with no

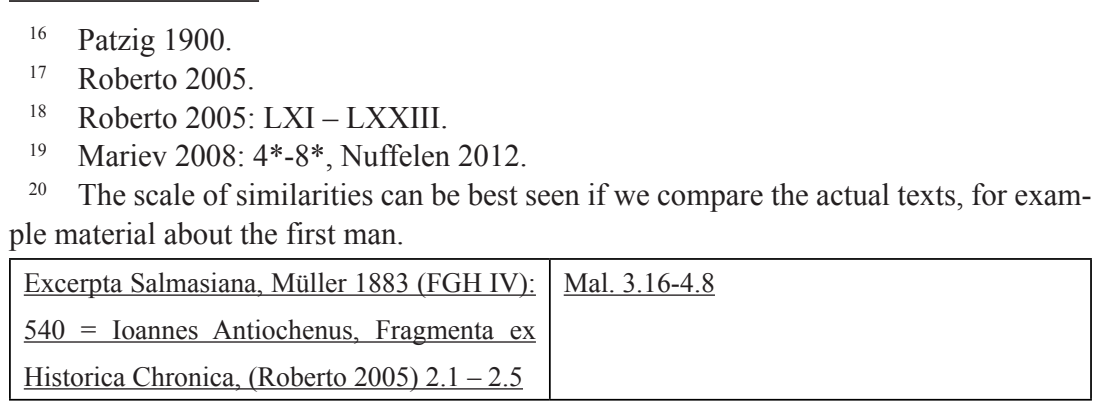


earlier literary testimony. ${ }^{21}$ If we agree that the Excerpta hold legitimate fragments of John of Antioch's Chronicle, the conclusion must be that either the two authors had a common source, ${ }^{22}$ or that one had drawn on the other. ${ }^{23}$ If we do not agree on this attribution, there is still a question of the exact nature of the fragments found in the Excerpta and their connexion to Malalas (at least in the case of fragments which have their similar counterparts in Malalas' Chronicle).

The fragment of Malalas' Chronicle which interests us here is the story about Serug. It is one of those mythological and biblical narratives that can be found in a very similar form in the Excerpta. There are of course some differences, but similarities and shared oddities leave no doubt, as we will see later, that the two accounts are related. If we can establish this relation in respect to the story about Serug, then with some probability we can extrapolate our conclusions on all the fragments from the Excerpta, which have their relative counterparts in Malalas' Chronicle.

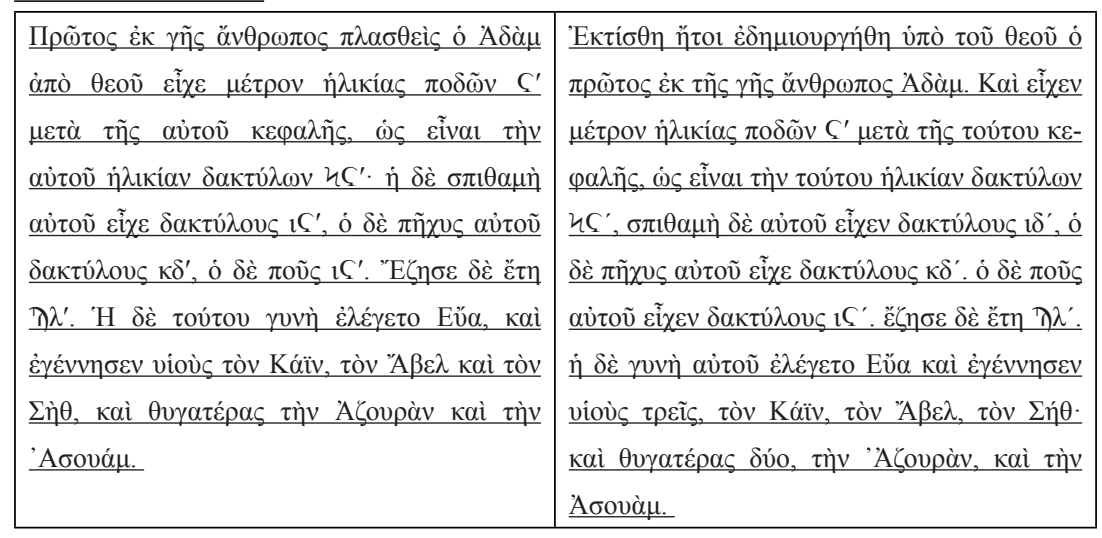

Both texts are almost identical. It is worth noting that the information on the dimensions of Adam, as well as the names of his daughters can be found only in Malalas' work (and works that draw on it) and in the Excerpta Salmasiana. This case proves true for many other parts of mythological and biblical narrative in both works.

${ }^{21}$ The most important of those is probably a euhemeristic narrative about Picus-Zeus.

22 Which is a theory of Treadgold (Treadgold 2007: 709-745), who proposed that Malalas and John of Antioch used John of Epiphaneia as their common source.

23 This was suggested by Whitby Mi 1990: 255-6. 


\section{SERUG, TERAH AND THE INTRODUCTION OF IDOLATRY}

Malalas places this story in the second book of his work right after a euhemerized mythological account about Thebes. ${ }^{24} \mathrm{He}$ indicates the change of the topic, and obviously of his source, by a phrase which

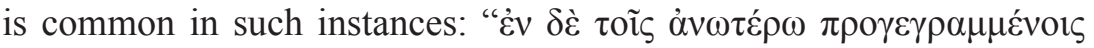

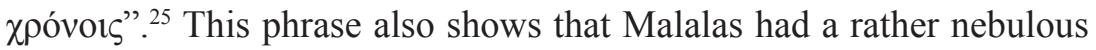
idea about the chronology of events, which probably means that his source did not provide him with that kind of information and he did not go to great lengths to find it in another source (for example in Eusebius' Chronicle, which does date those events). And indeed the text, which we will argue was the ultimate source of this story, was not a chronographical work.

We will now briefly recount the story as Malalas and the Excerpta tell it. The original Greek text of the two versions is also provided in parallel columns on the next pages. The story goes that there was a certain Serug, who was a descendant of Japheth, and who was the first one to introduce the cult of great deceased people. Malalas elaborates here on the idea of deification of great men after their death to some extent and says that he himself draws on the writings of Eusebius of Caesarea and Reginos, who is otherwise unknown to us. Malalas' account is much longer than the one in the Excerpta, but one can suppose that here the Excerpta are a shortened version of the text featured in Malalas' Chronicle, as it tells the same story in fewer words of which almost all are mirrored in Malalas' Chronicle. In the next stage the texts proceed to Abraham's father, Terah, who in turn is credited with being a creator and inventor of idolatry, a cult of statues of deified people. After this both texts say that a certain Hellen was the one who introduced idolatry into Greece. Malalas additionally mentions Jovan, another character responsible for spreading idolatry among Greeks, who is also said to have taken part in the building of the Tower of Babel. Malalas at the end of

\footnotetext{
24 Malalas $38.7-40.53$. The preceding story about the Theban empire is also very idiosyncratic and is also recounted in a very similar way in the Excerpta. There is a recent study devoted to this narrative by Pernet 2007.

25 Malalas 38.6.
} 
this story adds another discourse about the nature of idolatry, this time saying that he follows Plutarch. Even this overview should ring a bell, as in some parts it is simply in conflict with the Bible (Serug, according to the Bible, is not a descendant of Japheth, but of Shem), and in some other cases the information provided by Malalas and the Excerpta has no earlier literary attestation (for example the introduction of idolatry into Greece by Hellen and Jovan).

The multitude of detailed information in this narrative gives an impression that there are some written sources employed and indeed Malalas does not fail to name them. But the problem with these named sources is that we have no access to them, so we cannot really check the veracity of Malalas' allegations. On the other hand, we can be almost certain that he did not use an obvious source, the Bible (at least in the form that we are accustomed to) as there are contradictions with the biblical texts, and information completely absent in it. ${ }^{26}$

But is a well-known fact that during antiquity biblical tradition was transmitted not only by canonical books, as the canon, as we know it now, was established much later. It suffices to mention Josephus Flavius and his Antiquities of the Jews, where we find a plethora of biblical stories absent in the Bible. There are also works that despite their popularity in antiquity failed to become part of the Canon (at least in Europe). One of such works was The Book of Jubilees, sometimes called Lesser Genesis. ${ }^{27}$ And indeed it is the Book of Jubilees that bears some resemblance to the account featured in Malalas' Chronicle, ${ }^{28}$ as there seem to be a hint that Serug and Terah are implicated into the introduction of idolatry. ${ }^{29}$ But there exists another ancient text, which until now remained unnoticed by scholars who deal with Malalas, a text, which displays such a close resemblance to the story about Serug featured in Malalas' Chronicle and in the Excerpta, that there can be no doubt it was their ultimate source.

\footnotetext{
26 Gen.11.20-27

27 The book of Jubilees survived only in Ge'ez translation, as it was considered canonical only by Aethiopian Orthodox Church. We were using an English translation of the Ethiopic text prepared by Vanderkam (Vanderkam James C., The Book of Jubilees, Louven 1989).

28 It has been suggested that Malalas could use it, see Jeffreys 1996: 55-57.

29 Jubil. 11.6; 11.11-17. Terah, according to the Jubilees, was an idolater.
} 


\section{EPIPHANIUS' PANARION AND ANACEPHALEOSIS}

Roberto, who in his edition of John of Antioch fragments included the aforementioned Excerpta Salmasiana and therefore also the fragment about Serug and idolatry, noticed that there are some interesting similarities between this story and certain fragments of Panarion of Epiphanius of Salamis. Panarion, which was written in the $4^{\text {th }}$ century, lists all kinds of known heresies. ${ }^{30}$ Among these heresies pagan cults are also included, and among them the most important is "Hellenismos". It is this part of Panarion where Roberto found some similarities to the text about Serug, Terah and the introduction of idolatry present in the Excerpta Salmasiana, ${ }^{31}$ but there is another work closely related to Panarion, which includes a slightly altered version of the entry about "Hellenismos" which contains much more similarities to the texts in the Excerpta and Malalas' Chronicle. This work is called Anacephaleosis and it is an epitome of Panarion. ${ }^{32}$

Anacephaleosis is, as epitomes are bound to be, a shortened version of Panarion, but in some places the author of this work added substantial pieces of new material. This is especially the case in the account of "Hellenismos". We said earlier that both Malalas' and the Excerpta version of this story includes elements that cannot be found anywhere else. On the other hand, the version featured in Anacephaleosis is a rather traditional account of the story about Serug and Terah, as we find it in the Book of Jubilees. The similarities between Anacephaleosis' and Malalas' versions lay rather in the layout of the texts, their vocabulary with entire sentences hardly changed. The reason Malalas' text is so different is due to actually minor additions or deletions, which sometimes, however, change the meaning of the text substantially. As we said many times already, the version of Malalas and the one found in the Excerpta, are to a large extent the same, therefore comparisons of these two accounts along with the Anacephaleosis version of this story,

\footnotetext{
30 A good introduction to this work and its author is an introduction to the translation of the Epiphanius' works made by Williams (Williams 2009: xi-xxxv).

31 Roberto 2005: 42 (fr 17).

32 For more details, see Williams 2009: xvii.
} 
the earliest of them from a chronological point of view ${ }^{33}$, will enable us to see more clearly the interrelationship between all the three texts. Below we have the three texts put in parallel columns. Parts of text which present special interest are underlined.

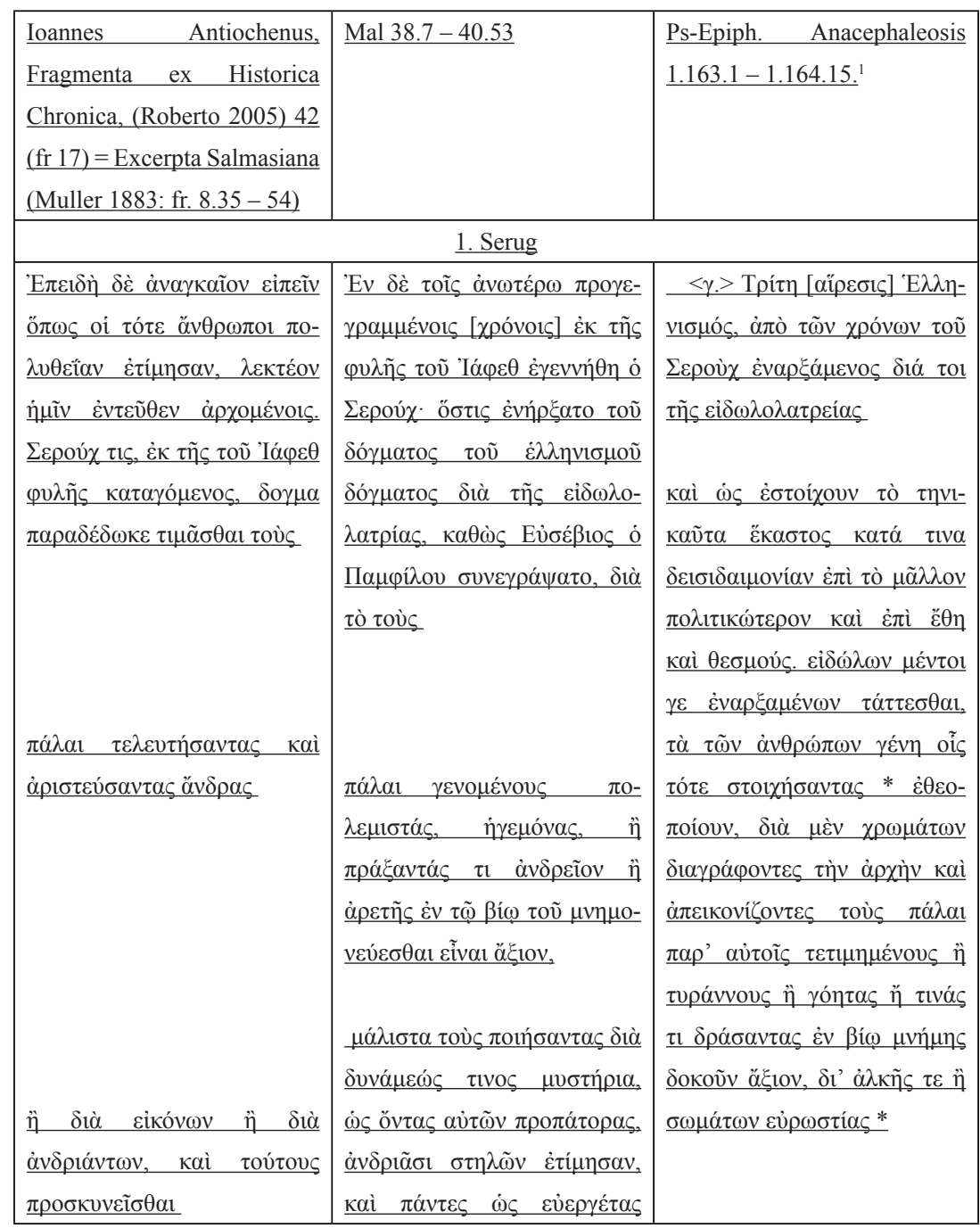

33 Anacephaleosis was already used by Saint Augustinus in his De haeresibus ad Quodvultdeum (Williams 2009: xvii). 


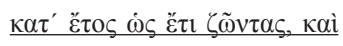

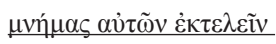

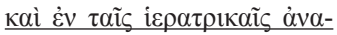

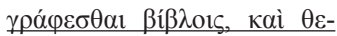

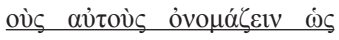

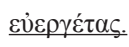

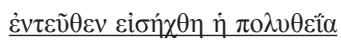

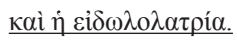

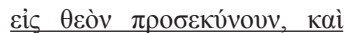

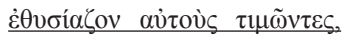

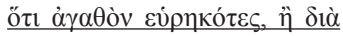

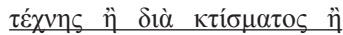

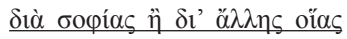

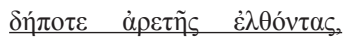

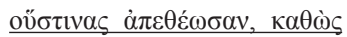

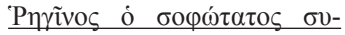

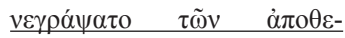
$\omega \theta \varepsilon \dot{\varepsilon} \tau \tau \omega \mathrm{V}$ ỏvó $\mu \alpha \tau \alpha$. oi $\delta \dot{\varepsilon} \mu \varepsilon \tau \grave{\alpha}$

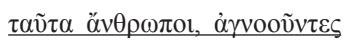

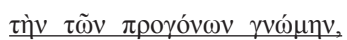

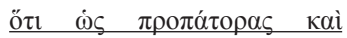
$\underline{\alpha} \gamma \alpha \theta \tilde{\omega} v \quad \dot{\varepsilon} \pi \mathrm{t} v 0 \eta \tau \dot{\alpha} \varsigma_{\varsigma} \dot{\varepsilon} \tau \dot{\mu} \mu \eta \sigma \alpha v$

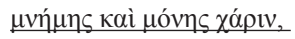

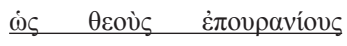

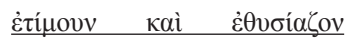

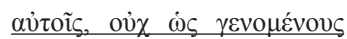

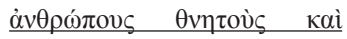

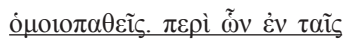

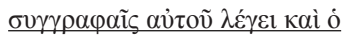

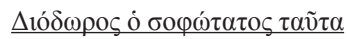

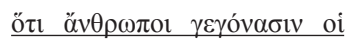
$\underline{\theta \varepsilon o i ́, ~ o u ́ \sigma \tau ı v a s ~ o i ~ a ̈ v \theta \rho \omega \pi o u ~}$

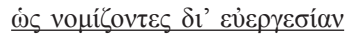

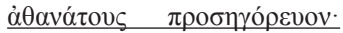

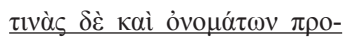

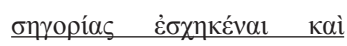

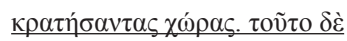

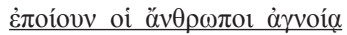

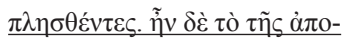

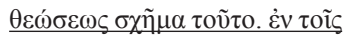

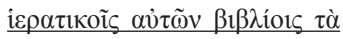

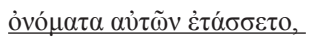




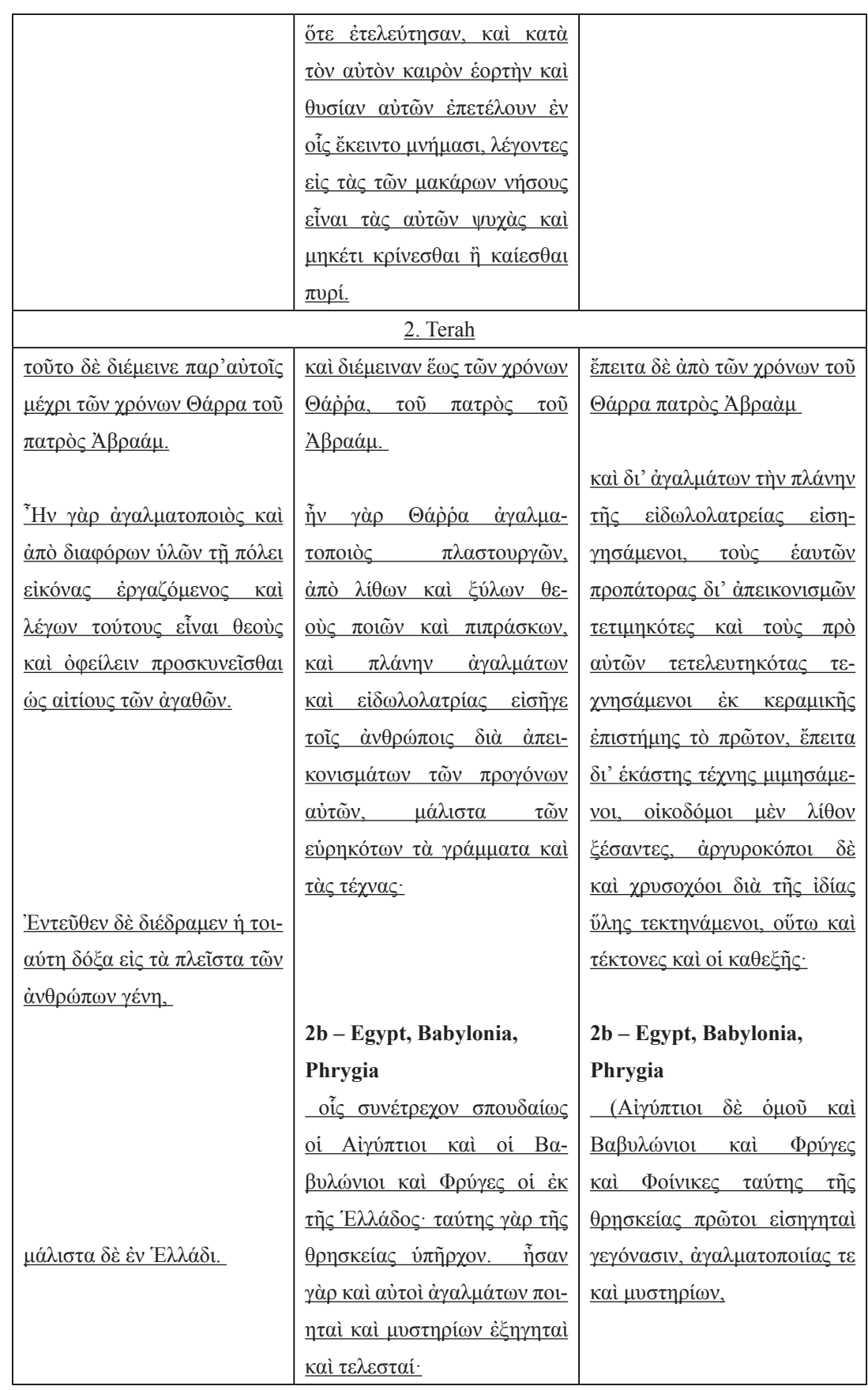




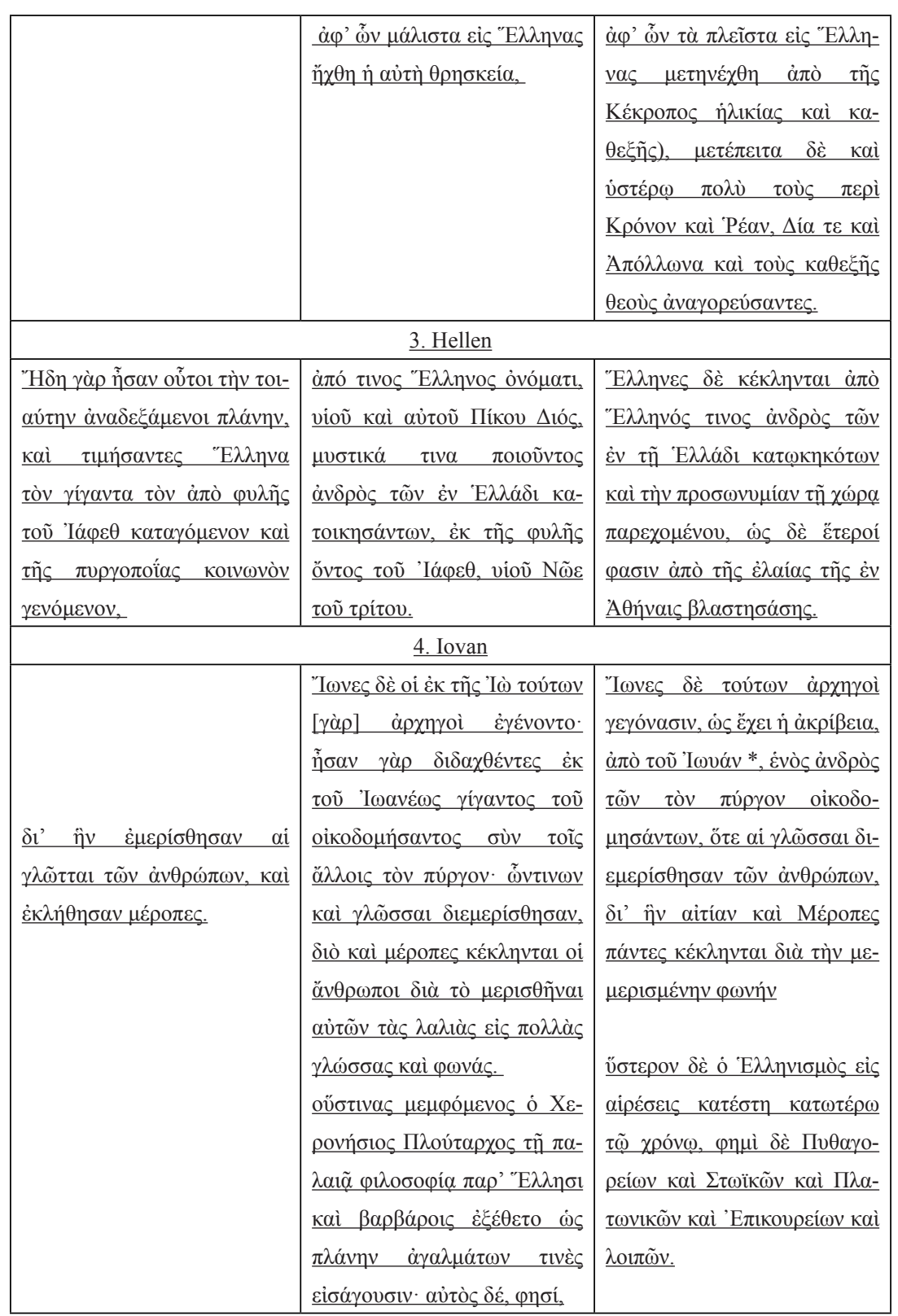




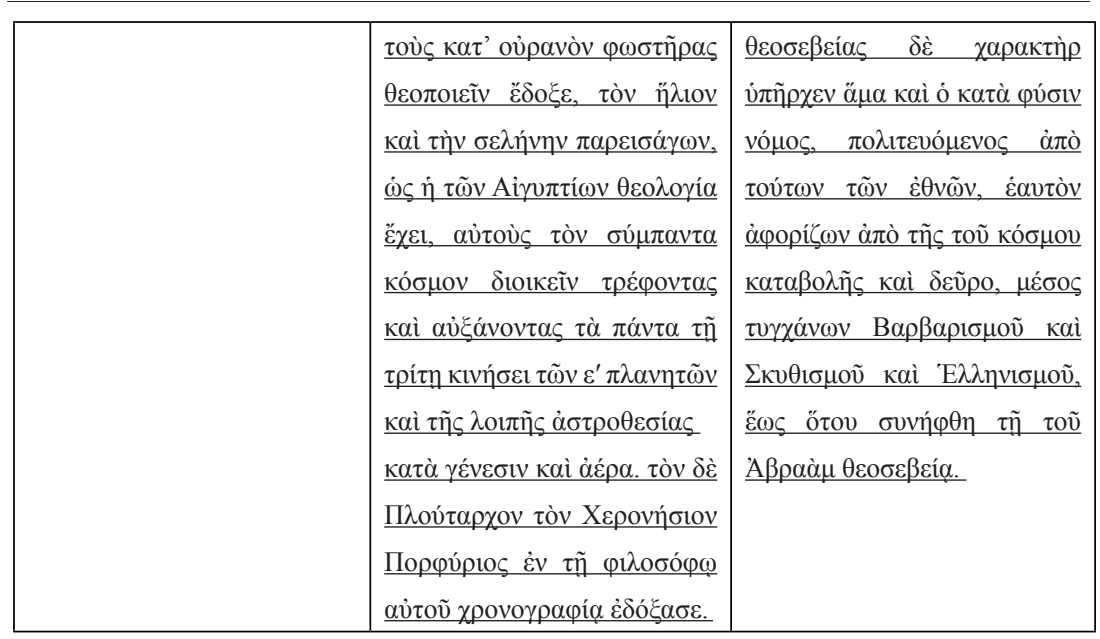

The three texts are very similar, and in some places nearly identical. The layout is basically the same. But sometimes similarities exist only between Malalas and the Excerpta and sometimes they are shared by all the texts. The prime example of the similarities between all the texts is the fragment about Terah, statues and their role in idolatry (2), examples of convergence only between Malalas and Anacephaleosis include the discourse about Phrygia and Egypt (2b). We will now focus on the selected fragments of special interest.

\section{SERUG (1)}

Serug was depicted in Malalas' Chronicle and in the Excerpta Salmasiana as the one who invented the cult of great deceased people. This is the first instance of such a statement completely unaccounted for in any other earlier written testimonies known to us. What is especially striking is that it is unsupported by the Genesis (nor by any other pseudoepigraph known to us). It is also absent from Anacephaleosis, which only states that idolatry originated during the times of Serug (the same statement we find in Panarion). Anacephaleosis does not contain any information that would be in disagreement with the version known from the Genesis and the Jubilees. The Anacephaleosis (and the Panarion) 
account is evidently dependent on the text of the Jubilees, where there are some more or less similar claims,${ }^{34}$ which is nothing new, as Epiphanius is well known for his familiarity with the Jubilees.

But there is another claim made by Malalas and the author of the Excerpta that is even more troubling, namely they both write that Serug is a descendant of Japheth, the son of Noah. But according to the Bible he is from the stock of Shem, as he is said to be the grandfather of Terah and the great grandfather of Abraham. ${ }^{35}$ Anacephaleosis does not contain such a claim, yet it is interesting that this work does not actually contradict Malalas, as it simply does not say who was Serug's ancestor. But this strange statement made by Malalas and the author of the Excerpta also shows that they were unaware of the tradition which says that Serug was the grandfather of Terah, Abraham's father, whose affiliation to the house of Shem is obvious (even for Malalas, as he shows it elsewhere). Again, Anacephaleosis does not say anything relevant concerning the relationship between Serug and Terah (and Abraham).

Taking into consideration the close similarity between the texts and the fact that Malalas and the Excerpta do not actually contradict Anacephaleosis, we can assume that the error concerning the ancestry of Serug comes from using Anacephaleosis as the only source, to which the author of a new version added some information which he deemed "logical". But someone could ask what kind of logic would push anyone to ascribe someone to the house of Japheth? To answer this question, we have to return to the claim about Serug being the inventor of the cult of great deceased people. Malalas in his Chronicle consistently presents the descendants of Shem as the "chosen people", those who have a special relasionship with God, and Japheth's descendants are for the most part pagan and idolatrous people. ${ }^{36}$ In this context it is indeed "logical" to assign the inventor of idolatry to Japheth's people. Yet this logic requires the first step, namely assuming that Serug was the inventor of paganism, something that does not appear in Anacephaleosis (and in other earlier works). Then what was the source of such a claim?

\footnotetext{
34 Jubil. 11.6; 11.11-17.

35 And so he has to be Shem's descendant (Gen 11.20-23).

36 Berthelot 2004: 44.
} 
But before we answer this question let us focus on the relationship of the texts.

Let us examine closely the texts featured in Malalas' Chronicle and Anacephaleosis where we hear about Serug and the invention of paganism.

\begin{tabular}{|c|c|}
\hline$\underline{\text { Malalas }}$ & Anacephaleosis \\
\hline 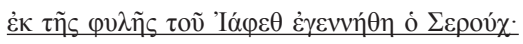 & 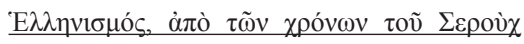 \\
\hline 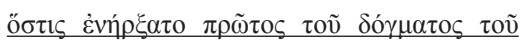 & 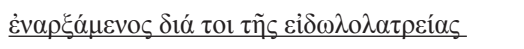 \\
\hline 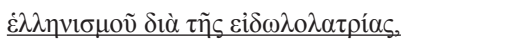 & \\
\hline
\end{tabular}

These are basically the same words put in different order, and this order makes all the difference. Let us point out the fact that if from Anacephaleosis' version we delete only two words ( $\tau \tilde{\omega} v \chi \rho o ́ v \omega v)$, it acquires the same meaning as Malalas' version. It seems therefore, that Malalas was basing here only on this fragment of Anacephaleosis and the change concerning the active role of Serug in inventing paganism was introduced either erroneously or Malalas had some good reasons to introduce this change. On the other hand, the Excerpta version is different in terms of the text layout and the words that are used:

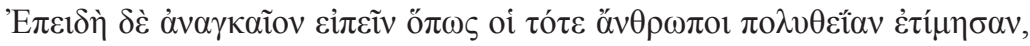

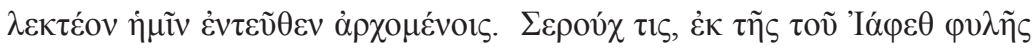

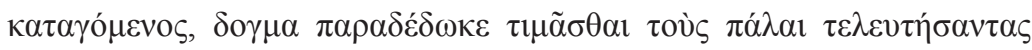

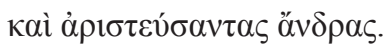

At the same time, it tells the same story as Malalas. Seeing these similarities and differences between the three versions, also knowing that Anacephaleosis is much earlier chronologically than Malalas, it can be safely assumed that the Malalas version comes directly from the text present in Anacephaleosis and the Excerpta is derived from the text similar to that of Malalas, that is from a text which already introduced the new information into the original text of Anacephaleosis. But as we said, one of those changes, that is attributing Serug to the house of Japheth, makes sense in the context of Malalas' Chronicle, therefore it 
seems more probable that the Excerpta were actually derived from Malalas' Chronicle and certainly the opposite is improbable.

There is always a possibility of the existance of an intermediary text between Malalas and Anacephaleosis, which would also be the source for the Excerpta (or John of Antioch). It should be noted, however, that if there was indeed an intermediary source, then Malalas would have to copy it entirely, because otherwise, if he decided to even slightly change the text of his source (as in the case of the Excerpta), so close verbal and syntactical similarities would be hardly possible. Therefore, the information about Serug being responsible for introducing idolatry was most probably invented by Malalas.

A very similar situation happens in the case of Terah, who is the topic of the next passage.

\section{TERAH (2)}

Below we have the Terah passage in Malalas' Chronicle and in Anacephaleosis. Let us examine it closely.

\begin{tabular}{|c|c|}
\hline Malalas $39.30-34$ & Anacephaleosis $1.163 .9-15$. \\
\hline 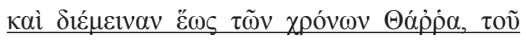 & 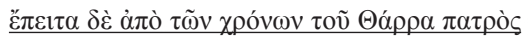 \\
\hline 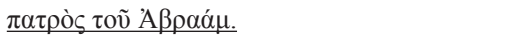 & $\underline{A \beta \rho \alpha \alpha ̀} \mu$ \\
\hline 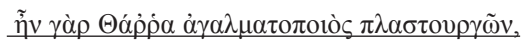 & $\underline{\kappa \alpha i ̀}$ \\
\hline 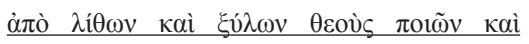 & \\
\hline$\underline{\pi l \pi \rho \alpha ́ \sigma \kappa \omega \nu,}$ & 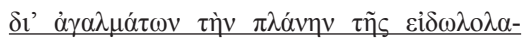 \\
\hline 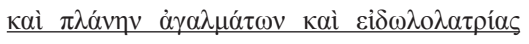 & 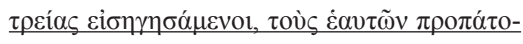 \\
\hline 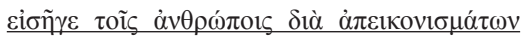 & 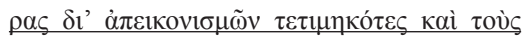 \\
\hline 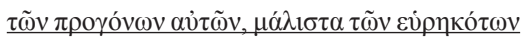 & 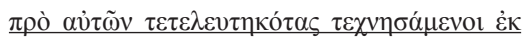 \\
\hline \multirow[t]{5}{*}{ 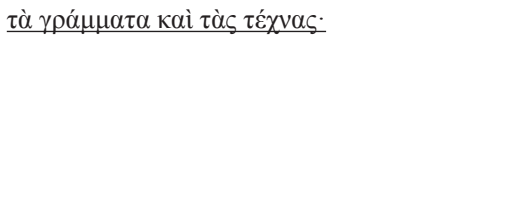 } & 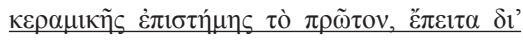 \\
\hline & 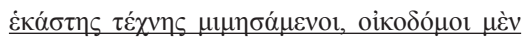 \\
\hline & 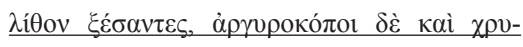 \\
\hline & 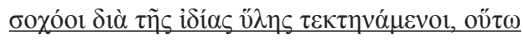 \\
\hline & 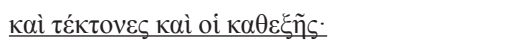 \\
\hline
\end{tabular}

Above all Malalas says that there was Terah, father of Abraham, who was a sculptor and who introduced the sin of idolatry: 


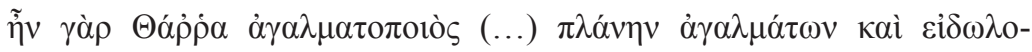

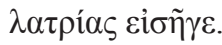

On the other hand, Anacephaleosis says that from the time of Terah, the father of Abraham, people introduced the sin of idolatry:

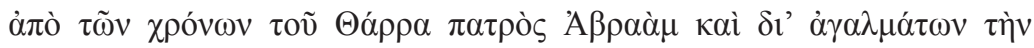

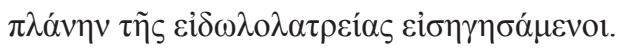

This happened according to Malalas through depiction of their ancestors,

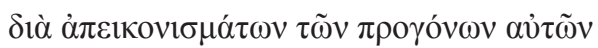

whereas Anacephaleosis states that it happened through depictions of their ancestors

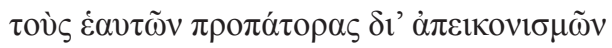

Again, even though it is quite evident that the two texts are closely related, there is difference in the meaning. Again, the Excerpta present a text which in meaning is close to the Malalas' version but there is substantial difference in wording. The difference between Malalas and Anacephaleosis versions is of the same kind as in the earlier case, and again if we delete just two (the same) words, namely $\tau \tilde{\omega} v \chi \rho o ́ v \omega v$, Anacephaleosis can be interpreted as if it said that it was Terah, by whom idolatry was introduced.

The extra-biblical tradition about Terah is much richer than in the case of Serug. We even find statements that he was the priest of idols, but until the times of Malalas' chronicle we hear nothing about him being the inventor of the statues of idols. It is then a fairly logical inference that as in the previous case Malalas is responsible also here for this change in the tradition concerning Terah.

But why Malalas decided to do it? Maybe he just overlooked these two words ( $\tau \tilde{\omega} v \chi \rho o ́ v \omega v)$ and thus introduced this change thinking he was following his source. But it would have to happen repeatedly not 
only with the already mentioned Serug and Terah, but also with Hellen, as we will soon see. Such a coincidence would be hardly possible.

We will return to this question and now we will turn our attention to another part of the Terah passage which deals with the materials employed in the construction of statues.

\begin{tabular}{|c|c|}
\hline$\underline{\text { Malalas }}$ & Excerpta Salmasiana \\
\hline 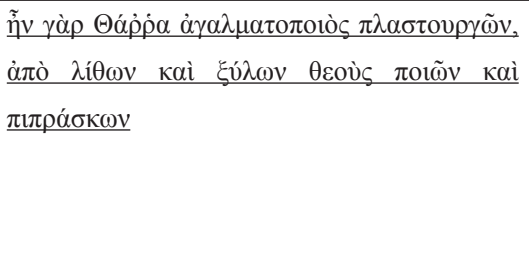 & 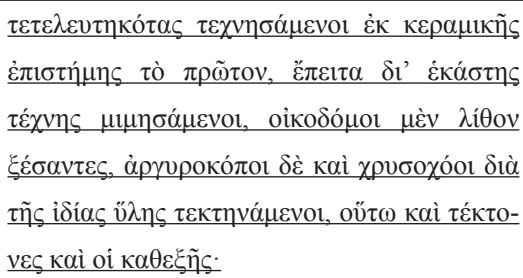 \\
\hline
\end{tabular}

First of all, Malalas' version is much shorter here than the corresponding part of the story in Anacephaleosis. In Malalas' version most of the discourse featured in Anacephaleosis is omitted and substituted

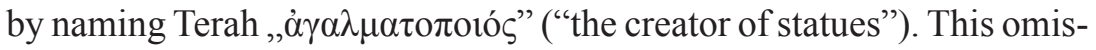
sion is understandable in the context, where Terah is the "creator of statues", as in the omitted text the author of Anacephaleosis says about craftsmen, who were constructing statues using various substances

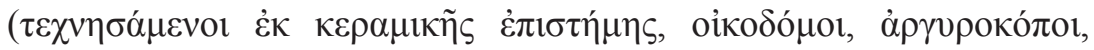

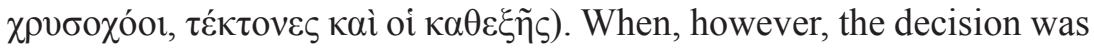
made to assign to Terah an active role in the construction of the statues, this passage was not very useful.

It seems then that this is the only substantial difference between the two text was introduced by someone, who in the first place assigned to Terah a more active role than he had in Anacephaleosis, therefore it seems that this change was a conscious choice and not an error, and that its author decided to change his source wherever he needed to adjust it to the active roles he assigned to characters he found in the sources of his story. At the same time wherever it was possible, that is wherever his source text did not need any adjustments, he left the original text nearly unchanged.

But let us examine more closely another part of the story, this time focused on Hellen, the eponymous Hero of Greeks. 


\section{HELLEN, THE EPONYMOUS HERO OF GREEKS}

Let us again put the three text alongside each other to see the similarities and differences more clearly.

\begin{tabular}{|c|c|c|}
\hline \begin{tabular}{lc} 
Excerpta & Salmasiana \\
Ioannes & \multicolumn{2}{c}{ Antiochenus } \\
Fragmenta & ex $\quad$ Historica \\
Chronica, & (Roberto 2005$)$ \\
$42.10-14$ &
\end{tabular} & Malalas $39.34-41$ & $\begin{array}{l}\text { Anacephaleosis } 1.163 .15 \\
=164.5 \text {. }\end{array}$ \\
\hline 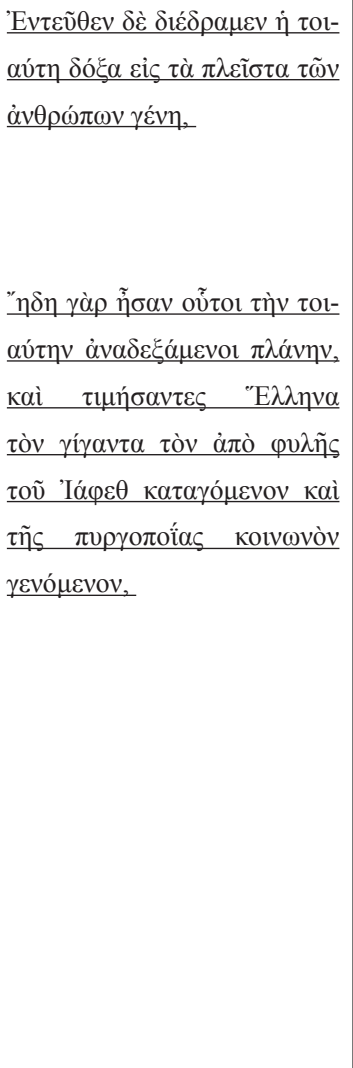 & 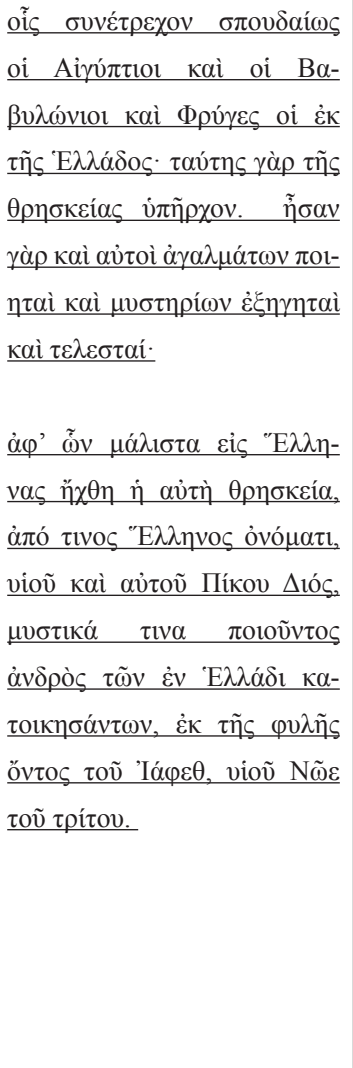 & 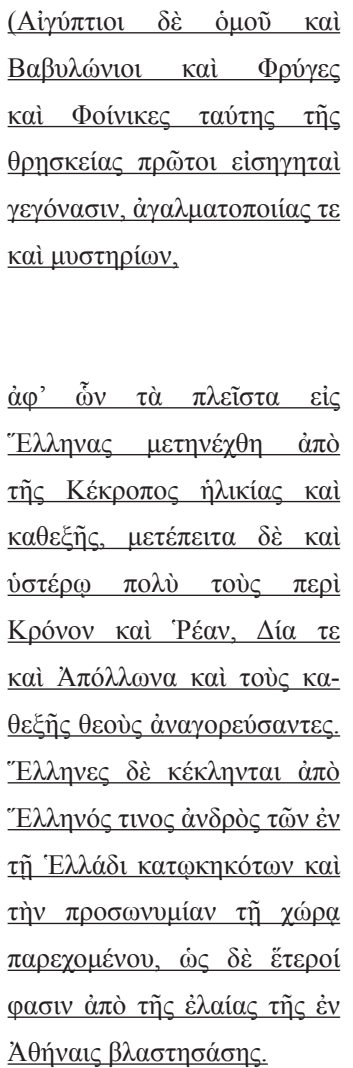 \\
\hline
\end{tabular}

The Excerpta say that Hellen took part in the construction of the Tower of Babel and was the one, who introduced the sin of idolatry into Greece. This is again, as was in the case of Serug and Terah, information 
found nowhere else in earlier literary works. This time though it is not in agreement with Malalas, who says only that Hellen introduced idolatry and not that he took part in the construction of the Tower of Babel.

Of course Hellen is recorded in some standard versions of the Greek mythology, he is there a demigod, son of Zeus and Pyrrha. ${ }^{37}$ Yet the idea that he had something to do with the construction of the Tower of Babel and the introduction of "Hellenismos" into Greece is new. So where did it come from? Let us compare the other two texts, that is Malalas with the part of the account concerning idolatry in Anacephaleosis. Anacephaleosis again says nothing new nor contradictory in view of the recorded tradition. It also mentions Hellen, ${ }^{38}$ but here he is only an eponymous hero, and not the builder of the Tower of Babel and he does not bear responsibility for the introduction of "Hellenismos" into Greece. The Malalas version and Anacephaleosis share in this short account so much that it actually seems to be simply copied, with some really minor changes, from the original text. Malalas has a bit shortened version of the account but it is so mainly due to some omissions. One difference is the fact that Malalas mentions Picus-Zeus, who replaced Kronos and Rea found in the Anacephaleosis. This one is of minor importance, as it is simply adjusting the source text to a context of the Malalas Chronicle, where Picus-Zeus was the most important of (euhemerized) pagan gods. The second change is again expected, as it conforms with the earlier ones, that is assigning active roles to the characters in spreading idolatry. Malalas therefore says that Hellen introduced idolatry into Greece, and not only, as Anacephaleosis, has it, that he gave his name to the Greeks. Anacephaleosis as in earlier cases, just notes that idolatry was introduced (not saying by whom), and Malalas says by whom, and this perpetrator happens to be the one, who is also mentioned by Anacephaleosis in the same story.

I already mentioned that the Excerpta Salmasiana differ from the account by Malalas, as it states that Hellen was a giant and was " $\tau \tilde{\eta} \varsigma$

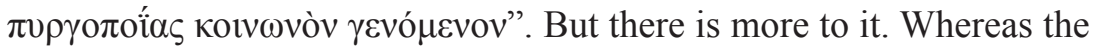
Excerpta tell a very similar story to that of Malalas (with the aforementioned exception concerning Hellen), in terms of phraseology and

\footnotetext{
37 Apollod. Bibl. 1.7.2-3, Cas. Dio 4.60.2, Hyg. Fab.155; Strab. 8.7.1, 9.5.6.

38 Panarion, of which Anacephaleosis is epitome, does not say a word about Hellen.
} 
wording it is quite different and notably shorter than the Malalean account. There is an even greater contrast in comparison with the Anacephaleosis. It is quite interesting that the Excerpta in one instance have a sentence with the same wording and content as Malalas (namely the one, which tells that Hellen is from the house of Japheth: $\dot{\varepsilon} \kappa \tau \tilde{\eta} \varsigma \varphi v \lambda \tilde{\eta} \varsigma$

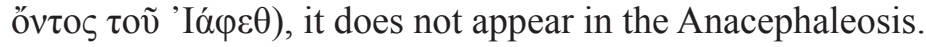

To sum up, Malalas represents nearly the same text as Anacephaleosis with a minor change similar to the one observed in the case of Terah and Serug. However, this change introduces a piece of information which has no precedence in earlier literature. The author of Excerpta tells nearly the same story as Malalas, but adds also the information about the Tower of Babel. It has different wording in comparison with Malalas (and Anacephaleosis), and it is shorter. On the other hand, the only instance where Excerpta has the same wording as Malalas is a sentence which does not appear in text of Anacephaleosis. But before we draw further conclusions let us now look at another part of the story which appears in all three versions, the etymological explanation of a word $\mu \varepsilon \dot{\rho} о \pi \varepsilon \varsigma$.

\section{DIAMERISMOS AND MEPOПE $\Sigma$}

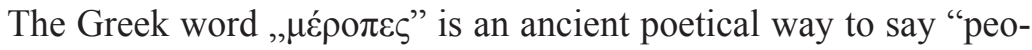
ple" that was employed in epic poetry. It literally means ,those who give out articulate sounds". Etymology in late antiquity was quite a popular way to demonstrate erudition or to make an argument, ${ }^{39}$ and for the most part it had little to do with accuracy. The short etymological discourse about the word $\mu \varepsilon$ é $\pi \varepsilon \varsigma$ found in the three versions of the story is exactly of this kind.

\begin{tabular}{|c|c|c|}
\hline \begin{tabular}{ll} 
Excerpta & Salmasiana \\
Ioannes & \multicolumn{2}{c}{ Antiochenus, } \\
Fragmenta & ex $\quad$ Historica \\
Chronica, & (Roberto 2005) \\
$\underline{42.14}$ &
\end{tabular} & $\underline{\text { Malalas } 39.43-45}$ & $\underline{\text { Anacephaleosis } 1.164 .7-9}$ \\
\hline
\end{tabular}

39 Amsler 1989: 15-56. 


\begin{tabular}{|c|c|c|}
\hline 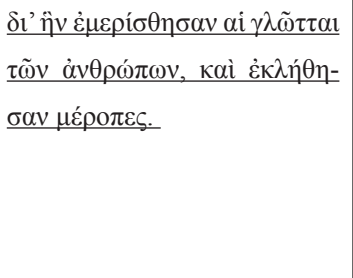 & 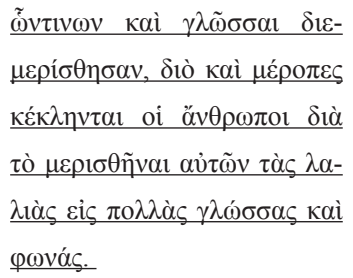 & 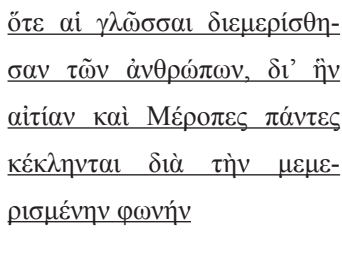 \\
\hline
\end{tabular}

All three versions tell us that $\mu \varepsilon \varepsilon^{\prime} \sigma \pi \varepsilon \varsigma$ comes from the verb $\delta 1 \alpha \mu \varepsilon \rho i \zeta \omega$ (to divide), and it was used to describe people because their first language was divided into many as a result of division (" $\delta 1 \alpha \mu \varepsilon \rho 1 \sigma \mu{ }^{\prime} \varsigma$ ") of the people after the unsuccessful attempt to build the Tower of Babel. This folk etymology is accounted for the first time in the Panarion of Epiphanius $^{40}$, the work of which Anacephaleosis is an epitome, therefore its appearance in Anacephaleosis is understandable. As in previous examples also here Malalas' version is nearly the same as the one found in Anacephaleosis. On the other hand the version present in the Excerpta is a bit shorter from the two texts and also presents some differences with regard to the wording (for example Malalas, Anacephale-

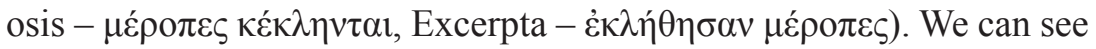
again therefore, that Malalas is close to the ultimate source, whereas the Excerpta is much modified and shortened. It is again obvious that Malalas could not possibly use as his source the version found in the Excerpta. On the other hand, the Excerpta seem to be an abridgment of the version found in Malalas, as the Excerpta include some sentences that are found in Malalas' Chronicle but not in Anacephaleosis. Let us move to the next part of this story, the analysis of which will further corroborate this thesis.

\section{JOVAN OR JOAN, THE EPONYMOUS HERO OF IONIANS}

The story about Jovan is present only in Malalas and Anacephaleosis, where it continues the theme of the aforementioned etymology of

\footnotetext{
$40 \quad$ Epiph. Panar. 1.176.6.
} 
the word $\mu \varepsilon \dot{\rho} \rho \pi \varepsilon \varsigma$. The Excerpta, as we will see, even though they do not mention him at all, also bear traces of familiarity with this part of the narrative.

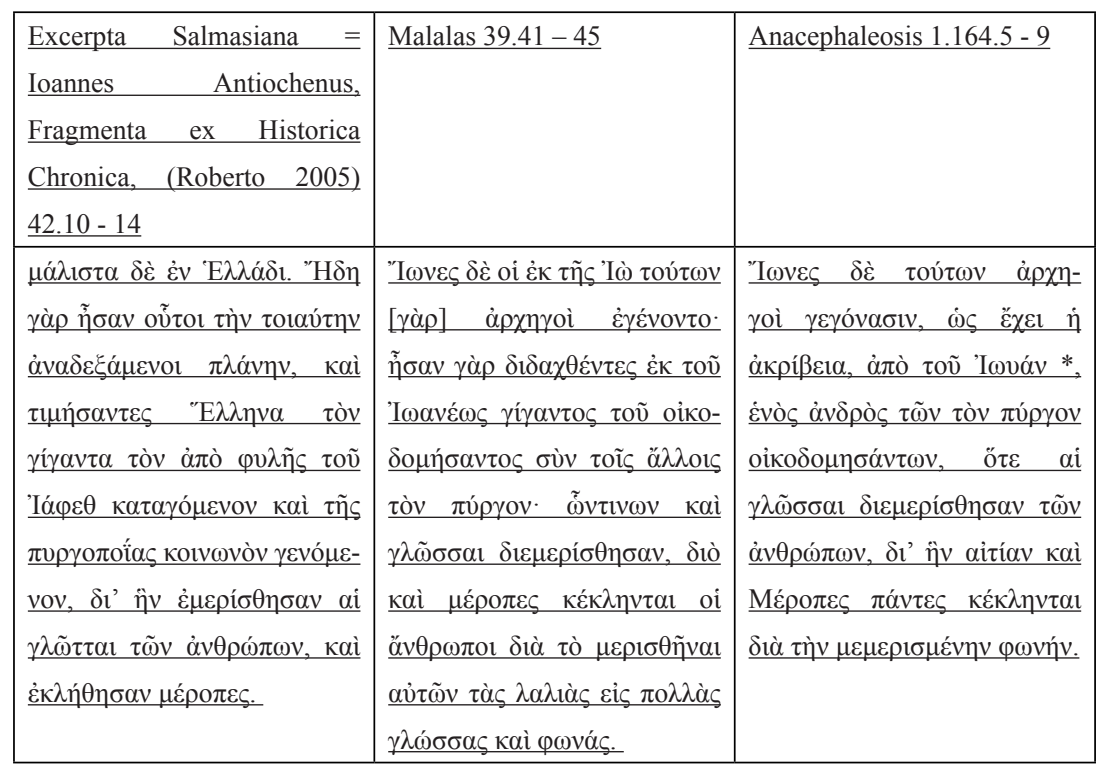

Anacephaleosis states that Ionians became rulers of the Greeks, and that they originated from Jovan, who was one of the builders of the Tower of Babel, whose unsuccessful construction resulted in the division of languages. Malalas has a slightly different version as according to him Ionians where descendants of Io and Ioan was their teacher of idolatry, but apart from that the two stories are alike. Again, in Malalas work Jovan, who was taken from his source, is assigned an active role. Adding information about Io is understandable only in the context of Malalas' whole Chronicle, where Io is a very important character in the story of the foundation of Antioch, Malalas' native city which plays an unusually important role in his world chronicle.

Jovan is a figure that can actually be found in the Bible. ${ }^{41}$ The idea of connecting this biblical figure with Greeks is not only easily understandable taking into account the popularity of etymological

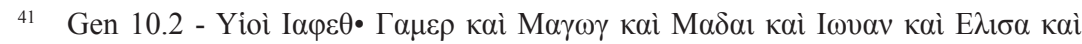

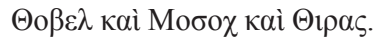


explanation and endeavor to Christianize the whole history, but also probably correct, as Jews in their description of people, known to them, in the time of writing the Genesis used the designation of Greeks that is still widespread in the languages spoken in the Middle East. So it comes as no surprise that first Christian chronicles mentioned him as the progenitor of Greek people. ${ }^{42}$ In this context Anacephaleosis just follows the old ways. But there is one exception to it Jovan has never been depicted as one of the builders of the Tower of Babel, or at least we know no other examples than Anacephaleosis and it is true even with regard to Panarion.

Jovan (in a slightly changed form, namely 'I $\omega \alpha v \varepsilon \tilde{v} \varsigma$ ) is featured in Malalas' Chronicle, although he is not the eponymous hero anymore, but a giant, propagator of idolatry among the Greeks. But besides this, as we said earlier, the two versions are nearly identical and there can be no doubt that Malalas' version has been based on Anacephaleosis.

The author of the Excerpta, even though he does not mention Jovan, makes manifest some resemblance to the text of Malalas. If we look closer into the story about Hellen featured in the Excerpta, which we have analyzed earlier, we can notice that it is placed exactly where the story about Jovan happens to be in the other two texts. What is more, Hellen in the Excerpta has the same epithets that are ascribed by Malalas to Jovan, that is in Malalas' Chronicle - Jovan is a giant and a builder of the Tower of Babel and the same is true, as we discussed above, in the case of Hellen in the Excerpta. What is more Malalas' version slightly differs from Anacephaleosis in that it does not say that Jovan is a giant. It seems to be one of minor additions made to the original source by Malalas as again "giants" play quite an important role in his Chronicle, where biblical and mythological (Greek) giants are "unified" into one race and serve as one more device to unite biblical and Greek accounts about early history of the world. We also mentioned earlier that Excerpta account of Hellen does seem to include

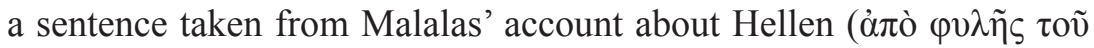

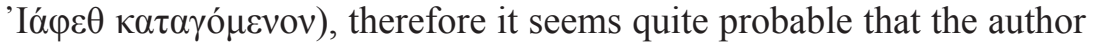
of the Excerpta merged the two stories, the one about Jovan and the second one about Hellen, which he had taken from Malalas.

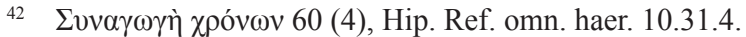




\section{CONCLUSIONS}

Our analyses of the three versions of the story about the introduction of idolatry found in Anacephaleosis, Malalas' Chronicle and the Excerpta Salmasiana lead us to some conclusions about their interrelationship:

1. The version found in Anacephaleosis is certainly the first step and the source for the other versions. It does not contain many new additions to the known tradition.

2. Malalas (or his source which would have to be identical with his Chronicle) drew on the version present in Anacephaleosis.

3. The author of the Excerpta Salmasiana in writing his version used the Malalas version.

Our findings do not provide us with an answer to the question whether Malalas had at his disposal the entire text of Anacephaleosis or only a part of it concerning "Hellenismos". We think that it is more probable that Malalas did not have access to the rest of the Anacephaleosis, as there are no other traces of him using this work in the rest of his Chronicle, yet to prove it would require a separate study. We can also ask a question whether Malalas here only copied a part of a different work, which in turn drew on Anacephaleosis, or maybe it is Malalas who used Anacephaleosis as his source and transformed it into a new version. Again, we think that he himself was responsible for the readjustment of the Anacephaleosis version, as his version displays differences with regard to the original version, which makes sense in the context of his whole chronographical work, like attributing Serug to Japeth and ascribing active roles to all the historical characters, but to prove this would require yet another study.

On the other hand, the fact that we can so clearly see the interrelationship between the Excerpta and Malalas' Chronicle corroborates the theory that the Excerpta, at least in the part which closely corresponds to Malalas, is not a collection of fragments from John of Antioch, but rather from Malalas. This would mean that the marginal note "غं $\tau \dot{\varepsilon} \rho \alpha$

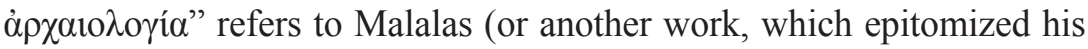
Chronicle) and not John of Antioch. It means that probably all other narratives shared by the Excerpta and Malalas are taken from Malalas and 
this would have profound consequences for Malalean scholars, who will have to look at the mythological and biblical part of his chronicle as something which is not a result of a simple rephrasing of some other work -a theory which had its strongest supporter in the supposed existence of a parallel work, of which the Excerpta would be testimony.

\section{BIBLIOGRAPHY}

Agusta-Boularot S., Beaucamp J., Bernardi A.-M., Caire E. (eds.), 2006, Recherches sur la Chronique de Jean Malalas II, Paris.

Amsler M., 1989, Etymology and Grammatical Discourse in Late Antiquity and the Early Middle Ages, Amsterdam.

Beaucamp J. (ed.), 2004, Recherches sur la Chronique de Jean Malalas, Paris. Beaucamp J., 2006, 'Le Passé Biblique et l'Histoire Juive: La Version De Jean Malalas', [in:] S. Agusta-Boularot et al. (ed.), Recherches sur la Chronique de Jean Malalas II, Paris, pp. 19-33.

Berthelot K., 2004, 'La Chronique de Malalas et les Traditions Juives', [in:] J. Beaucamp (ed.), Recherches sur la Chronique de Jean Malalas, Paris, pp. 37-51.

Boissevain U.P., 1887, 'Über die dem Ioannes Antiochenus zugeschriebenen Excerpta Salmasiana', Hermes 22, pp. 161-178.

Croke B., 1990, 'Modern study of Malalas', [in:] E. Jeffreys et al. (eds.), Studies in John Malalas, Sydney, pp. 325-340.

Croke B., 2010, 'Uncovering Byzantium's Historiographical Audience', [in:] R. Macrides (ed.), History as Literature in Byzantium, Aldershot, pp. 25-54.

D'Alfonso F., 2006, Euripide in Giovanni Malala, Alessandria.

de Boor C., 1899, 'Zu Johannes Antiochenus', Hermes 34, pp. 298-304; 480.

Garstad B., 2009, 'Joseph as a model for Faunus-Hermes: Myth, history, and fiction in the fourth century', Vigiliae Christianae 63/5, pp. 493-521.

Garstad B., 2002, 'The Excerpta Latina Barbari and the 'Picus-Zeus Narrative", Jahrbuch für Internationale Germanistik 34/1, pp. 259-313.

Garstad B., 2005, 'The Tyche Sacrifices in John Malalas: Virgin Sacrifice and Fourth-Century Polemical History', Illinois Classical Studies 30, pp. 83-136.

Horling E., 1980, Mythos und Pistis. Zur Deutung heidnischer Mythen in der christlichen Weltchronik des Johannes Malalas, Lund.

Jeffreys E., Croke B., Scott R. (eds.), 1990, Studies in John Malalas, Sydney. 
Jeffreys E., 1990, 'Malalas' Sources', [in:] E. Jeffreys et al. (eds.), Studies in John Malalas, Sydney, pp. 167-216.

Jeffreys E., 1996, 'The Chronicle of John Malalas, Book I: A Commentary', [in:] P. Allen, E. Jeffreys (eds.), The Sixth Century: End or Beginning?, Brisbane, pp. 52-74.

Mariev S., 2008, Ioannis Antiocheni fragmenta quae supersunt, Berlin-New York.

Nuffelen P. Van, 2012, 'John of Antioch, Inflated and Deflated. Or: How (Not) to Collect Fragments of Early Byzantine Historians', Byzantion 82, pp. 437-450.

Patzig E., 1900, 'Die hetera archaiologia der Excerpta Salmasiana', Byzantinische Zeitschrift 9, pp. 357-369.

Patzig E., 1892, Johannes Antiochenus und Johannes Malalas, Leipzig.

Pernet Ch., 2007, 'Le Récit de l'OEdipodie chez Jean Malalas', Byzantion 77, pp. 349-393.

Roberto U. (ed.), 2005, Ioannis Antiocheni Fragmenta ex Historia Chronica. Introduzione, edizione critica e traduzione, Berlin.

Sotiriadis G., 1888, Zur Kritik des Johannes von Antiochia, Leipzig.

Sotiroudis P., 1989, Untersuchungen zum Geschichtswerk des Johannes von Antiocheia, Thessaloniki.

The Panarion of Epiphanius of Salamis, 2009, tr. Frank Williams, Leiden.

Treadgold W., 2007, 'The Byzantine World Histories of John Malalas and Eustathius of Epiphania', The International History Review 29/4, pp. 709-745.

Whitby M., 1990, 'Review: Untersuchungen zum Geschichtswerk des Johannes von Antiocheia by Panagiotis Sotiroudis', The Classical Review, New Series 40/2, pp. 255-256. 